\title{
EFFECT OF OPERATIONAL PARAMETERS OF MICROWAVE VACUUM DRYING COMBINED WITH HOT-AIR PRE-DRYING TO PHYSICAL, SENSORY, AND NUTRITIONAL PROPERTIES OF DRIED APPLE SNACK
}

\author{
S. Ferenczi ${ }^{\mathrm{a}}$, Zs. Cserhalmi ${ }^{\mathrm{a}}$, B. Visnyei ${ }^{\mathrm{b}}$, V. Szücs a and B. CzuKor ${ }^{\mathrm{a} *}$ \\ aDepartment of Technology and Food chain analysis, Food Science Research Institute, \\ H-1022 Budapest, Herman Ottó út 15. Hungary \\ ${ }^{b}$ Department of Microbiology and Biotechnology, Corvinus University of Budapest, \\ H-1118 Budapest, Somlói út 14-16. Hungary
}

(Received: 14 April 2015; accepted: 27 July 2015)

\begin{abstract}
Microwave vacuum drying is a novel and mild food preserving technology. Beside its basic preserving function, it can be combined with other technologies, like hot-air drying. As a result of this combination, special snack can be produced from apple. The product is characterized by its unique consistency, high nutritional value, and consumer preference. In this work physical (dry mass content, hardness, bulk density, and colour), sensory (appearance, colour, odour, taste, texture) and nutritional (antioxidant activity and total phenolics) properties of dried apple snack were investigated as a function of pre-drying, microwave energy input, and batch weight. For evaluation of data, central composite experimental design was applied. According to the results, the physical properties of products produced by microwave vacuum drying combined with hot-air pre-drying (CMVD) mainly depend on the specific energy input. Higher specific energy input results higher dry mass content, which is associated with harder consistency, lower bulk density, and positive consumer perception as well. Bulk density had an optimum point of batch weight at $336 \mathrm{~g}$. Higher value of pre-dried dry mass content resulted lighter colour but less antioxidant activity and less total phenolics, therefore shorter hot-air drying and prolonged microwave vacuum drying is recommended.

Keywords: microwave vacuum drying, apple snack, drying parameters, hot-air drying, MVD, CMVD
\end{abstract}

Drying has been used for decades as one of the main food preserving techniques. Nowadays, hot-air drying is the most simple and widespread technology for drying of fruit. Beside its simplicity, the technology is characterized by low energy efficiency and long drying time (BONDARUK et al., 2007). Furthermore, the quality of dried product suffers from several drawbacks, like reduced phenolic compounds (IGUAL et al., 2012), because of the heat damage to plant cells (Bонм et al., 2002). Microwave vacuum drying (MVD) is a novel and mild food preserving and producing technology, which - compared to hot-air drying - is characterized by better energy efficiency and increased drying rate (SCAmAn et al., 2014). The product has higher antioxidant activity (FIgIel, 2010) and a porous and uniform texture (THERDTHAI \& ZHоU, 2009). The product's colour change is not significant, resulting higher sensory preference (SUNJKA et al., 2004).

The technology is capable of drying a wide range of fruit and vegetables, for example pear, strawberry, raisin grape, avocado, apple, potato, and carrot. The MVD of potato cubes showed that drying technique affects composition, colour, mechanical properties, and microstructure (BONDARUK et al., 2007). The drying rate is strongly affected by microwave

\footnotetext{
* To whom correspondence should be addressed.
} Phone: +36-1-796 0420; e-mail: s.ferenczi@cfri.hu 
power and slightly affected by vacuum pressure during the drying of carrot (CuI et al., 2004). Compared to sun-dried raisins, grapes dried with MVD equipped with infrared temperature controller exhibited better preservation of nutritional values (CLARY et al., 2007). The drying rate was found to depend on the drying conditions, like microwave power, vacuum pressure, and sample size, in cases of apple, avocado, mushroom, pear, and strawberry (PAPPAs et al., 1999). Different combinations of freeze drying and MVD of apple showed that the application of microwaves significantly affected phenolics and pectin contents and aroma (HuANG et al., 2012). A detailed investigation was made with strawberry, related to initial moisture content and microwave power, showing that low initial moisture content and high microwave power lead to products with low density, porous structure, but shows disadvantages with respect to moisture evaporation rate and energy utilization (KRULIS et al., 2005). According to the literature review, it can be stated that each raw material requires different technological parameters.

Apple proved to be an excellent raw material for MVD snack product, owing to its pleasant aroma (Li et al., 2010), appropriate cell structure, consumer acceptance, preferred sensory properties (SzŰCS et al., 2014), and high nutritional value (FERENCZI et al., 2014). Despite the fact that MVD is more widely studied, the international literature has still limited knowledge about the properties of MVD combined with hot-air pre-drying (CMVD), especially in case of apple. The research activity of CMVD is also justified by the solution to the limited processing capacity of MVD by the combination.

The aim of this work was to characterize technological parameters affecting product quality and to define the optimum point for these parameters. In order to reach this goal, physical, sensory, and nutritional properties of dried apple snack have been investigated as a function of pre-drying, microwave energy input, and batch weight. For evaluation of data, central composite experimental design was applied. The correlation between consumerrelated, sensory properties and physical properties (dry mass content, hardness, bulk density, and colour) is discussed. Furthermore, two relevant nutritional properties of apple are also measured in CMVD product, the antioxidant activity and total phenolics contents. The properties of raw material are shown as well, excluding hardness. The nutritional properties of pre-dried sample and MVD sample (without pre-drying) are measured as well. For ease of comparability, the results are related to dry mass content.

\section{Materials and methods}

Raw material was Idared (Malus domestica Idared) apple, obtained from the eastern part of Hungary, Szabolcs-Szatmár-Bereg County. The apples were washed, the ovary was removed, the bulk was cut to 16 equal radial pieces, and then hot-air drying was applied by a laboratoryscale hot-air dryer (L-MIM 200). Airflow was set to $0.9 \mathrm{~m} \mathrm{~s}^{-1}$ and the temperature was $50{ }^{\circ} \mathrm{C}$. Drying time varied between 8 and 10.5 hours, depending on the required dry mass content. After the hot-air pre-drying, a 24-hour rest was applied to the samples in refrigerator, to let the inner and surface moisture equalize and then MVD was applied (Fig. 1). For this purpose, a custom-designed MVD instrument was applied, containing a cylindrical stainless steel vacuum chamber with a conical dome for better vapour removal. The samples were located in a rotary polytetrafluoroethylene (PTFE) tray. Microwaves were generated by two $850 \mathrm{~W}$ rated output magnetrons, operating at $2450 \mathrm{MHz}$. The vacuum was kept constant at $5 \mathrm{kPa}$ by 
a rotary vane vacuum pump, connected to a shell and tube heat exchanger for vapour condensation. The cooling water for the heat exchanger was provided by a compressor and was kept circulated by a pump.

After drying, the samples were put in light-, oxygen-, and humidity-sealing foil package to avoid rehydration and oxidation. All measurements were done after packaging.

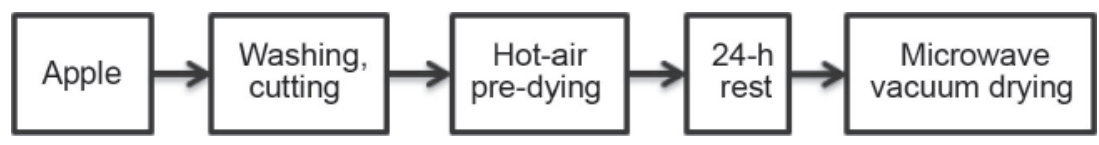

Fig. 1. Flow chart of microwave vacuum drying combined with hot-air pre-drying

Central composite experimental design was used for building quadratic model with response surface methodology. Alpha value was chosen for rotatability (1.6818). Three factors were used: pre-dried dry mass content (calculated by $100 \times$ dry mass/total weight), specific energy input, and batch weight. The design results in 8 "corner points", 6 "alpha star points", and 2 repetitions of centre points. The values were calculated based on experiences of preliminary studies, where $300 \mathrm{~g}, 70 \%$ pre-dried dry mass content apple was successfully treated with $1.68 \mathrm{~kJ}$ per g pre-dried sample microwave energy input (FERENCZI \& CZUKOR, 2012). This was set for centre point.

Dry mass content was measured by the current Hungarian Standard (1980). Each sample was measured in triplicates.

Hardness was measured by a Lloyd LR5K plus material tester instrument, equipped with TG84 type adapter. The sample was held in a square-shaped, bottom-perforated container and was pushed by a surface of $0.01 \mathrm{~m}^{2}$ adapter. Beside the constant compression rate $(50$ $\mathrm{mm} \mathrm{min}^{-1}$ ), the device measures the mechanical resistance of the sample during the $50 \mathrm{~mm}$ compression distance. Each sample was measured in triplicate.

Bulk density was measured by a gas pycnometer. The method relies on the compressibility of air, which makes the application suitable for measuring the volume of solids. The structure of the CMVD samples is hard air-filled cellular structure. For this reason, an air-impermeable layer was used to cover the surface of the samples. Each sample was measured in 5 replicates.

Surface colour was measured by Konica Minolta Croma Meter CR 400. The device uses CIELAB colour space, where $\mathrm{L}^{*}$ stands for lightness ( 0 for black, 100 for white) $-\mathrm{a}^{*}$ is green, $+a^{*}$ is red, $-b^{*}$ is blue, and $+b^{*}$ is yellow tint. Each sample was measured in triplicates.

The amount of the total phenolics was measured with Folin-Ciocalteu reagent (SINGLETON \& Rossi, 1965).

For the analysis of the antioxidant activity DPPH free radical scavenging was utilized (YAmAGUCHI et al., 1998).

Sensory analysis was done with the help of 14 trained experts. All 16 samples would have been difficult to order for the experts, therefore four samples were selected, which represent a central composite 3 -factor $2^{\wedge}(3-1)$ design (Table $\left.1 / \mathrm{A}\right)$.

According to the 20-point scoring system with weighted factors (Hungarian STANDARD, 1989), the 'appearance', 'colour', 'odour', 'taste', and 'texture' of the dried apple pieces were evaluated, associated with 1.0, 0.8, 0.4, 0.6, 1.2 weighted factors, respectively. Maximum score of weighted factors was 20 and scores for each property were between 1 and 5 (MolNÁR, 1991). As the effect of the different treatments manifested mainly in the change 
of the 'texture' and the 'appearance', these characteristics got higher weight. After the scoring, experts were asked to rank the samples according to their overall preference. Results of the scoring were analysed with the help of the SPSS 21 statistical software (mean, standard deviation, paired $t$-test) and results of the sensory ranking (Kramer test) were evaluated with the application of the current standard (ISO, 2006).

\section{Results and discussion}

Results of physical and nutritional properties are shown in Table 1/A and 1/B, respectively, and the statistical results are shown in Table 2.

Table 1/B. Sample parameters and results of nutritional properties

\begin{tabular}{|c|c|c|c|c|c|}
\hline \multirow{2}{*}{$\begin{array}{l}\text { Sample } \\
\text { No. }\end{array}$} & \multicolumn{3}{|c|}{ Parameters } & \multicolumn{2}{|c|}{ Nutritional properties } \\
\hline & $\begin{array}{l}\text { Batch weight } \\
\text { (g) }\end{array}$ & $\begin{array}{l}\text { Pre-dried dry } \\
\text { mass content } \\
\quad(\%)\end{array}$ & $\begin{array}{c}\text { Specific } \\
\text { energy input } \\
\left(\mathrm{kJ} \mathrm{g}^{-1}\right)\end{array}$ & $\begin{array}{l}\text { Antioxidant activity } \\
\text { (mmol Trolox/100 g } \\
\text { dry mass) }\end{array}$ & $\begin{array}{c}\text { Total phenolics (mg } \\
\text { gallic acid/100 g dry } \\
\text { mass) }\end{array}$ \\
\hline$* 1$ & 200.0 & 60.0 & 1.44 & $5.47 \pm 0.83$ & $730.8 \pm 70.5$ \\
\hline 2 & 200.0 & 60.0 & 1.96 & $5.03 \pm 0.90$ & $666.6 \pm 79.3$ \\
\hline 3 & 200.0 & 80.0 & 1.44 & $4.14 \pm 0.84$ & $377.2 \pm 15.77$ \\
\hline$* 4$ & 200.0 & 80.0 & 1.96 & $3.72 \pm 0.55$ & $325.8 \pm 87.6$ \\
\hline 5 & 400.0 & 60.0 & 1.44 & $4.79 \pm 0.75$ & $436.7 \pm 17.0$ \\
\hline *6 & 400.0 & 60.0 & 1.96 & $5.63 \pm 0.87$ & $421.4 \pm 23.9$ \\
\hline$* 7$ & 400.0 & 80.0 & 1.44 & $3.35 \pm 0.37$ & $493.2 \pm 60.0$ \\
\hline 8 & 400.0 & 80.0 & 1.96 & $3.61 \pm 0.54$ & $302.8 \pm 67.3$ \\
\hline 9 & 131.8 & 70.0 & 1.68 & $5.79 \pm 0.11$ & $488.1 \pm 13.4$ \\
\hline 10 & 468.2 & 70.0 & 1.68 & $3.71 \pm 0.10$ & $517.5 \pm 40.0$ \\
\hline 11 & 300.0 & 53.2 & 1.68 & $5.43 \pm 0.32$ & $939.6 \pm 22.2$ \\
\hline 12 & 300.0 & 86.8 & 1.68 & $4.79 \pm 0.29$ & $289.9 \pm 19.5$ \\
\hline 13 & 300.0 & 70.0 & 1.24 & $4.55 \pm 0.08$ & $639.9 \pm 49.4$ \\
\hline 14 & 300.0 & 70.0 & 2.12 & $4.68 \pm 0.44$ & $592.2 \pm 3.6$ \\
\hline 15 & 300.0 & 70.0 & 1.68 & $4.62 \pm 0.31$ & $562.6 \pm 38.7$ \\
\hline 16 & 300.0 & 70.0 & 1.68 & $3.94 \pm 0.44$ & $413.5 \pm 29.5$ \\
\hline Average & 300.0 & 70.0 & 1.68 & 4.58 & 512.4 \\
\hline Raw & & & & $9.26 \pm 0.95$ & $636.5 \pm 13.5$ \\
\hline $\begin{array}{l}\text { Pre-dried } \\
\text { ( } 70 \% \text { dry } \\
\text { mass) }\end{array}$ & & & & $2.60 \pm 0.17$ & $462.7 \pm 17.5$ \\
\hline MVD & & & & $4.54 \pm 0.31$ & $647.6 \pm 58.2$ \\
\hline
\end{tabular}

*: indicates the selected samples for sensory analysis 


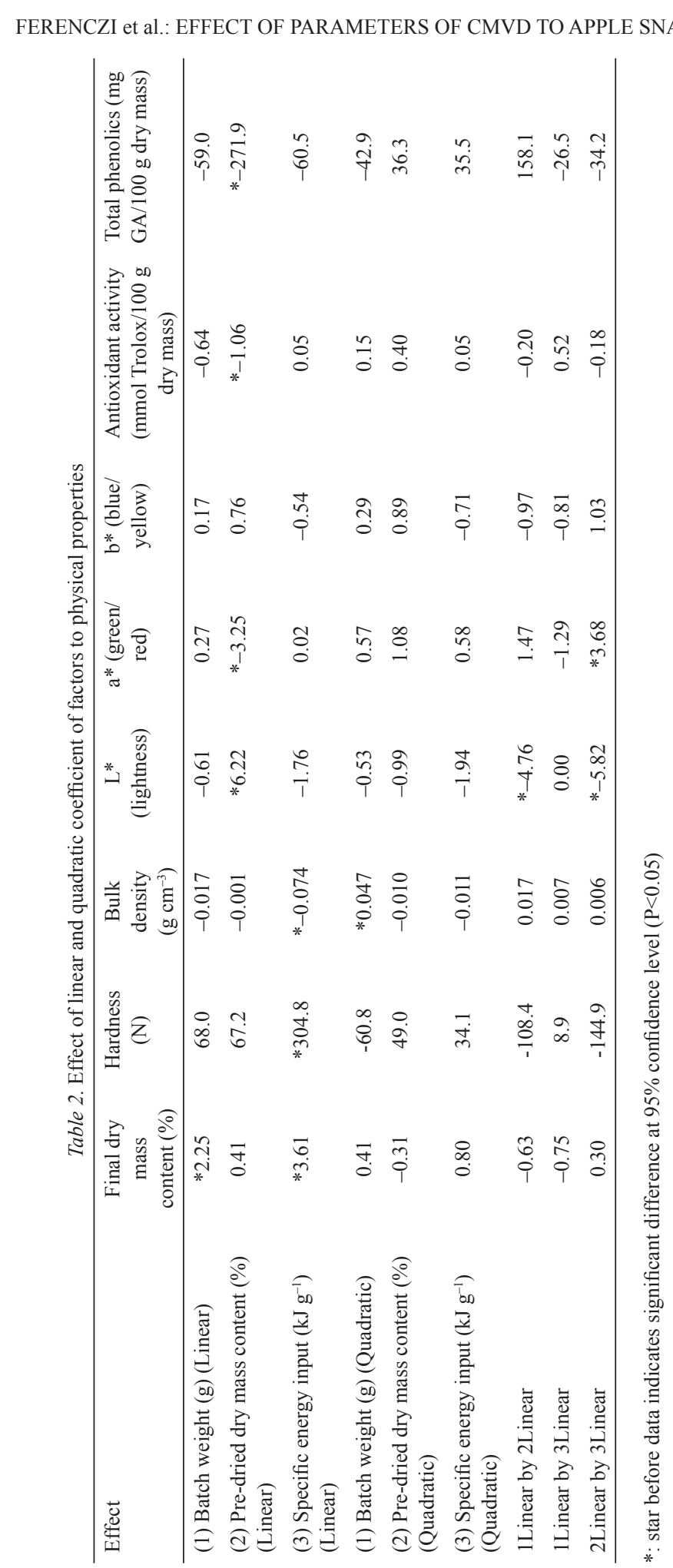




\subsection{Final dry mass content}

Results from the statistical analysis show that final dry mass content significantly depends on the energy input and less, but still significantly, on the batch weight. Raising the energy input by $1.00 \mathrm{~kJ} \mathrm{~g}^{-1}$ resulted $3.61 \%$ increase of dry mass content (Table 2), which correlates with former literary results (Cur et al., 2004; KRULIS et al., 2005).

Final dry mass content is an important indicator of the absorption of the microwave energy. The significant effect of batch weight to final dry mass content is explained by the phenomenon that absorption efficiency of microwave energy rises with higher batch weight of heated material.

\subsection{Hardness}

Hardness of the samples was significantly influenced by specific energy input, thus more energy makes the product harder. A strong correlation can be observed between hardness and final dry mass content; drier products are also harder and they are both depend mainly on specific energy input.

\subsection{Bulk density (b.d.)}

Sensory characteristics (puffy and crunchy structure) are the main factors influencing the dried apple product selection of the Hungarian consumers (Szücs et al., 2014). Low bulk density is related to the mentioned structure. This quality property depends significantly and mainly on specific energy input (s.e.); more energy makes lower bulk density, which means higher specific volume. Bulk density also depends on the quadratic coefficient of batch weight (b.w.), which means it has an optimum (and minimum) point at $336 \mathrm{~g}$ (from the equation of the model:

b.d. $=0.6771-0.0019 \times$ b.w. $-0.0109 \times$ s.e. +2.5882 E $-6 \times$ b.w. ${ }^{2}+0.0001 \times$ b.w. $\times$ s.e. $-0.0509 \times$ s.e. $\left.{ }^{2}\right)$.

The overall bulk density $\left(0.273 \mathrm{~g} \mathrm{~cm}^{-3}\right)$ is one quarter of raw apple's $\left(1.110 \mathrm{~g} \mathrm{~cm}^{-3}\right)$.

\subsection{Colour}

Lightness significantly depends on pre-dried dry mass content; higher pre-dried dry mass content products are lighter. As reported by studies (KORBEL et al., 2013), the inactivation of polyphenol-oxidase (PPO) is greatly influenced by water activity. The lower the water activity, the lower the thermal stability is. Higher pre-dried dry mass content means that the sample took more time in the hot-air drier at low water activity, which means higher PPO degradation, thus lighter colour. Compared to raw apple, an average 13\% lightness reduction can be observed, which is significant, but the darker colour of the product does not bother consumers' product selection (Szücs et al., 2014).

Value of a* (green/red shade) correlates with lightness, as higher pre-dried dry mass content products are less red. The value of $b^{*}$ (blue/yellow shade) was not affected significantly by the examined parameters. 


\subsection{Sensory analysis}

Statistical analysis showed that all 5 characteristics and total score are significantly influenced by specific energy input, with positive coefficient. By other words, higher specific energy input results higher sensory properties. Appearance, colour, texture, and total score are also significantly affected by batch weight, with positive coefficient as well.

Characteristics of sample 6 were scored as the best, while the lowest results were obtained for sample 1 . The former was treated with higher energy input and had higher batch weight, whereas the latter got less energy and had lower batch weight. According to the experts, sample 1 was rubbery, gummy, and dark, while sample 6 apple was puffy, crunchy, and tasty (Table 3).

Results of the sensory ranking underlined the observation of the scoring, that apple sample 6 was significantly $(\mathrm{P} \leq 0.05)$ better, while sample 1 worse than the others. In general, it can be concluded that the technological parameters can be identified in the sensory characteristics.

Table 3. The average weighted scores and the standard deviations of each characteristic of the selected samples for sensory analysis

\begin{tabular}{lcccccc}
\hline $\begin{array}{l}\text { Sample } \\
\text { No. }\end{array}$ & $\begin{array}{c}\text { Appearance } \\
(5)\end{array}$ & $\begin{array}{c}\text { Colour } \\
(4)\end{array}$ & $\begin{array}{c}\text { Odour } \\
(2)\end{array}$ & $\begin{array}{c}\text { Taste } \\
(3)\end{array}$ & $\begin{array}{c}\text { Texture } \\
(6)\end{array}$ & $\begin{array}{c}\text { Total } \\
(20)\end{array}$ \\
\hline 1 & $3.36^{\mathrm{c}} \pm 0.50$ & $2.74^{\mathrm{b}} \pm 0.41$ & $1.40^{\mathrm{c}} \pm 0.21$ & $2.14^{\mathrm{b}} \pm 0.31$ & $2.91^{\mathrm{d}} \pm 0.62$ & $12.56^{\mathrm{d}} \pm 0.76$ \\
4 & $4.07^{\mathrm{b}} \pm 0.43$ & $3.40^{\mathrm{a}} \pm 0.51$ & $1.53^{\mathrm{b}} \pm 0.27$ & $2.55^{\mathrm{a}} \pm 0.33$ & $4.89^{\mathrm{b}} \pm 0.84$ & $16.70^{\mathrm{b}} \pm 1.39$ \\
6 & $4.54^{\mathrm{a}} \pm 0.50$ & $3.54^{\mathrm{a}} \pm 0.38$ & $1.83^{\mathrm{a}} \pm 0.19$ & $2.68^{\mathrm{a}} \pm 0.30$ & $5.79^{\mathrm{a}} \pm 0.45$ & $18.37^{\mathrm{a}} \pm 1.55$ \\
7 & $4.36^{\mathrm{a}} \pm 0.50$ & $3.43^{\mathrm{a}} \pm 0.38$ & $1.51^{\mathrm{b}} \pm 0.29$ & $2.29^{\mathrm{b}} \pm 0.40$ & $4.24^{\mathrm{c}} \pm 0.60$ & $15.84^{\mathrm{c}} \pm 1.24$ \\
\hline
\end{tabular}

Mean values with different superscript letters within a column $(\mathrm{a}, \mathrm{b}, \mathrm{c}, \mathrm{d})$ differ significantly $(\mathrm{P} \leq 0.05)$.

Furthermore, a strong correlation can be observed between sensory and physical properties. Final dry mass content, hardness, and bulk density can be associated with sensory texture property. All mentioned properties are significantly dependent on specific energy input.

Regarding the results, the increase of specific energy input results in better product quality. Yet, too much energy input can cause browning or even burning (FERENCZI et al., 2011), therefore an optimum amount of energy input must be found, which is enough for drying the product and establish its special consistency, but does not result in overheating, thereby burning.

\subsection{Nutritional properties}

Both antioxidant activity and total phenolics content significantly depend only on pre-dried dry mass content in the same way. Lower pre-dried dry mass content results higher antioxidant activity and higher total phenolics content. In other words, lower pre-dried dry mass content means shorter hot-air drying and a prolonged MVD. Under these conditions, higher antioxidant activity and total phenolics content are achieved, which demonstrates the mildness of MVD to nutritional properties. 


\section{Conclusions}

According to the results, the physical properties of CMVD products mainly depend on the specific energy input. Higher specific energy input results higher dry mass content, which is associated with harder consistency and lower bulk density as well. Positive consumer perception is mainly due to these characteristics, therefore the value of specific energy input should be as high as possible without burning the product. Bulk density has an optimum point of batch weight at $336 \mathrm{~g}$. Pre-dried dry mass content has significant effect on colour and nutritional properties; higher value resulted lighter colour but less antioxidant activity and less total phenolics content. The slightly darker colour does not bother the consumers; however, they are looking for high nutrition value functional food. To meet these demands, lower pre-dried dry mass content, in other words shorter hot-air drying and prolonged microwave vacuum drying is recommended. For this instrument, within the examined range, this value is $60 \%$ dry mass content.

\section{References}

Bohm, M.E., BADE, M. \& Kunz, B. (2002): Quality stabilisation of fresh herbs using a combined vacuum-microwave drying process. Adv. Food Sci., 24(2), 55-61.

Bondaruk, J., Markowski, M. \& BŁaszczak, W. (2007): Effect of drying conditions on the quality of vacuummicrowave dried potato cubes. J. Food Eng., 81, 306-312.

Clary, C.D., Meija-Meza, E., Wang, S. \& Petrucci, V.E. (2007): Improving grape quality using microwave vacuum drying associated with temperature control. J. Food Sci., 72, 23-28.

Cui, Z.-W., Xu, S.-Y. \& Sun, D.-W. (2004): Microwave-vacuum drying kinetics of carrot slices. J. Food Eng., 65, $157-164$.

Ferenczi, S. \& Czukor, B. (2012): Combined hot-air and microwave vacuum drying of Jonathan apple. CEFood 2012 6th Central Congress on Food, 2012.05.24. Novi Sad, Serbia, Abstract book, p. 287.

Ferenczi, S., Czukor, B. \& Cserhalmi, Zs. (2011): Légárammal kombinált mikrohullámú vákuumszárítás II. Jonatán alma légáramú előszárítással kombinált mikrohullámú vákuumszárítási kísérletei. (Combined air- and microwave-vacuum drying II. Combined hot-air pre-drying and microwave vacuum drying of Jonathan apple). Élelmiszer Tudomány Technológia, LXV(2), 15-20.

Ferenczi, S., Czukor, B. \& Cserhalmi, Zs. (2014): Evaluation of microwave vacuum drying combined with hot-air drying and compared with freeze- and hot-air drying by the quality of the dried apple product. Period. Polytech. Chem., 58(2), 111-116.

Figiel, A. (2010): Drying kinetics and quality of beetroots dehydrated by combination of convective and vacuummicrowave methods. J. Food Eng., 98, 461-470.

Huang, L.L., Zhang, M., Wang, L.-P., Mujumdar, A.S. \& Sun, D.-F. (2012): Influence of combination drying methods on composition, texture, aroma and microstructure of apple slices. LWT-Food Sci. Technol., 47(1), $183-188$.

Hungarian Standard (1980): Tartósított élelmiszerek nedvességtartalmának meghatározása (Preserved foodstuffs. Determination of moisture content). MSZ 4220:1980

Hungarian Standard (1989): Tartósitott élelmiszerek érzékszervi birálata. (Preserved food products. Sensory analysis). MSZ 1801:1989

Igual, M., García-Martínez, E., Martín-Esparza, M.E. \& Martínez-Navarrete, N. (2012): Effect of processing on the drying kinetics and functional value of dried apricot. Food Res. Int., 47, 284-290.

ISO (2006): Sensory analysis - Methodology - Ranking. No. ISO 8587:2006

Korbel, E., Servent, A., Billaud, C. \& Brat, P. (2013): Heat inactivation of polyphenol oxidase and peroxidase as a function of water activity: a case study of mango drying. Dry. Technol., 31, 1675-1680.

Krulis, M., KÜHnert, S. \& LeIKer, M. (2005): Influence of energy input and initial moisture on physical properties of microwave-vacuum dried strawberries. Eur. Food Res. Technol., 221, 803-808.

Li, Z., Vijaya Raghavan, G.S. \& Wang, N. (2010): Apple volatiles monitoring and control in microwave drying. LWT-Food Sci. Technol., 43, 684-689. 
MolnÁR, P. (1991): Élelmiszerek érzékszervi vizsgálata (Sensory analysis of foodstuffs). Akadémiai Kiadó, Budapest, pp. 158-173.

Pappas, C., Tsami, E. \& Marinos-Kouris, D. (1999): The effect of process conditions on the drying kinetics and rehydration characteristics of some MW-vacuum dehydrated fruits. Dry. Technol., 17(1-2), 158-174.

Scaman, C.H., Durance, T.D., Drummond, L. \& Sun, D-W. (2014): Combined microwave vacuum drying. -in: Sun, D.-W. (Ed.): Emerging technologies for food processing, Academic Press. San Diego, California, USA, pp. 507-533.

Singleton, V.L. \& Rossi, J.A. (1965): Colorimetry of total phenolics with phosphomolybdic-phosphotungstic acid reagents. Am. J. Enol. Viticult., 16(3), 144-158.

SunJKa, P.S., RenNie, T.J., Beaudry, C. \& Raghavan, G.S.V. (2004): Microwave-convective and microwave-vacuum drying of cranberries: A comparative study. Dry. Technol., 22, 1217-1231.

Szücs, V., Ferenczi, S., Cserhalmi, Zs. \& Szabó, E. (2014): Consumer acceptance of combined hot-air and microwave vacuum-dried apple pieces. Acta Universitatis Sapientiae, Alimentaria, 7, 109-119.

THerdthai, N. \& ZHou, W. (2009): Characterization of microwave vacuum drying and hot air drying of mint leaves (Mentha cordifolia Opiz ex Fresen). J. Food Eng., 91, 482-489.

Yamaguchi, T., Takamura, H., Matoba, T. \& Terao, J. (1998): HPLC method for evaluation of the free radicalscavenging activity of foods by using 1,1-diphenyl-2-picrylhydrazyl. Biosci., Biotech. Bioch., 62, 1201-1204. 